\title{
Cytonuclear diversity and shared mitochondrial haplotypes among Daphnia galeata populations separated by seven thousand kilometres
}

Mingbo Yin ${ }^{1 *}$, Xiaoyu Wang ${ }^{1}$, Xiaolin Ma ${ }^{1}$, Sabine Gießler ${ }^{2}$, Adam Petrusek ${ }^{3}$, Johanna Griebel ${ }^{4}$, Wei Hu ${ }^{1}$ and Justyna Wolinska, ${ }^{4,5}$

\begin{abstract}
Background: The zooplanktonic cladocerans Daphnia, present in a wide range of water bodies, are an important component of freshwater ecosystems. In contrast to their high dispersal capacity through diapausing eggs carried by waterfowl, Daphnia often exhibit strong population genetic differentiation. Here, to test for common patterns in the population genetic structure of a widespread Holarctic species, D. galeata, we genotyped two sets of populations collected from geographically distant areas: across 13 lakes in Eastern China and 14 lakes in Central Europe. The majority of these populations were genotyped at two types of markers: a mitochondrial gene (for $12 S$ rRNA) and 15 nuclear microsatellite loci.

Results: Mitochondrial DNA demonstrated relatively shallow divergence within D. galeata, with distinct haplotype compositions in the two study regions but one widely distributed haplotype shared between several of the Chinese as well as European populations. At microsatellite markers, clear separation was observed at both large (between China and Europe) and small (within Europe) geographical scales, as demonstrated by Factorial Correspondence Analyses, Bayesian assignment and a clustering method based on genetic distances. Genetic diversity was comparable between the sets of Chinese and European D. galeata populations for both types of markers. Interestingly, we observed a significant association between genetic distance and geographical distance for D. galeata populations in China but not in Europe.

Conclusions: Our results indicate relatively recent spread of D. galeata across wide expanses of the Palaearctic, with one mtDNA lineage of $D$. galeata successfully establishing over large distances. Despite a clear differentiation of Chinese and European D. galeata at a nuclear level, the pattern of genetic variation is nevertheless similar between both regions. Overall, our findings provide insights into the genetic population structure of a cladoceran species with extremely wide geographical range.
\end{abstract}

Keywords: Cyclical parthenogenesis, Cladocera, Genetic variation, Microsatellites, $12 S$ rRNA, Population structure

\footnotetext{
* Correspondence: yinm@fudan.edu.cn

${ }^{1}$ MOE Key Laboratory for Biodiversity Science and Ecological Engineering,

School of Life Science, Fudan University, Songhu Road, Shanghai 2005, China

Full list of author information is available at the end of the article
}

(c) The Author(s). 2018 Open Access This article is distributed under the terms of the Creative Commons Attribution 4.0 International License (http://creativecommons.org/licenses/by/4.0/), which permits unrestricted use, distribution, and reproduction in any medium, provided you give appropriate credit to the original author(s) and the source, provide a link to the Creative Commons license, and indicate if changes were made. The Creative Commons Public Domain Dedication waiver (http://creativecommons.org/publicdomain/zero/1.0/) applies to the data made available in this article, unless otherwise stated. 


\section{Background}

A major challenge in our understanding of biodiversity is why certain species have a wide distribution, spanning several biogeographical regions, while others have much more restricted ranges or are endemic. The cosmopolitanism view [1] holds that species with large population sizes and strong dispersal abilities maintain genetic homogeneity across widely dispersed geographical regions. For example, many freshwater invertebrate species were considered to be cosmopolitan. This conclusion was based on observed morphological similarities of specimens inhabiting different continents and interpreted as a result of efficient dispersal mechanisms (e.g. [2]). However, the classical view of cosmopolitanism has been challenged by extensive genetic studies. Specifically, despite the morphological similarities across broad geographical ranges, many freshwater zooplankton species, including rotifers and cladocerans, have been shown to display strong genetic divergence not only at a global scale, but even at regional levels (e.g. [3, 4]). At present, it is possible to detect even weak differentiation of population structure within species, because of the wide availability of sufficiently variable multi-locus nuclear and mitochondrial DNA (mtDNA) markers. Besides tracing maternal lines via mtDNA, local adaptation processes can be examined by analysis of nuclear polymorphism (e.g. [5-7]).

Here, we focus on a common and very widespread freshwater zooplankton species, the cladoceran Daphnia galeata G. O. Sars, 1863, to improve our understanding of its dispersal and genetic diversity over small and large geographic scales. Daphnia (Anomopoda: Daphniidae) are important components of freshwater ecosystems, being grazers of phytoplankton as well as a key prey item of planktivorous fish [8]. Daphnia are cyclical parthenogens; females mostly reproduce clonally by giving birth to parthenogenetic daughters. In unfavourable environments, however, Daphnia switch to the production of males and sexual eggs which require fertilization, and then enter diapause in a gastrula stage [9]. Daphnia galeata, a member of the D. longispina complex (taxonomy revised in: [10]), has a wide Holarctic distribution [11], being common in freshwater lakes in Europe, North America and Asia (e.g. [11-16]). This broad geographical range of D. galeata apparently results from long-distance passive dispersal of sexually produced diapausing eggs, which can be carried among water bodies by waterfowl (e.g. $[17,18])$. Surprisingly, despite the high dispersal capacity of anomopod cladocerans, substantial genetic differentiation has been detected among studied populations, across different Daphnia species (e.g. $[5,6])$.

Ishida and Taylor [12] surveyed D. galeata populations across Holarctic continents, using both a mitochondrial DNA (mtDNA) marker and a conservative nuclear marker (i.e. HSP90). One major mtDNA type of $D$. galeata was detected throughout the Holarctic with some haplotypes shared over long distances, even between Europe and North America. At the nuclear marker level, however, New and Old World D. galeata were clearly differentiated [12]. Moreover, there was a mismatch between the patterns observed at these markers: five nuclear but only four mitochondrial phylogroups were detected [12], which was explained by nuclear introgression from $D$. dentifera to $D$. galeata in the New World. However, populations from China, where D. galeata is a very common zooplankter [15], were not included in that previous survey, in which continental Asia was represented only by Siberian populations. Our recent study of the biogeography and diversity of $D$. galeata across China revealed low mtDNA variation; a common D. galeata haplotype (as resolved by sequencing of $12 \mathrm{~S}$ rRNA and cytochrome c oxidase subunit I) was widespread across China, Japan, Siberia and the Western Palaearctic [15]. We also detected many rare local mtDNA haplotypes in China, suggesting either that some time has passed since initial colonization, along with subsequent evolutionary change, or that multiple introductions occurred [15]. In contrast, nuclear differentiation based on variation of multiple microsatellite loci supported clear spatial differentiation among Chinese D. galeata populations even on a relatively small geographical scale (within $30 \mathrm{~km}$, [19]).

The aim of the present study was to compare patterns in the genetic population structure of the most widespread species of the D. longispina complex, D. galeata $[20,21]$, between two distant areas, and to identify common or potentially distinct features. We compared the genotypic diversity of two sets of D. galeata populations (from Eastern China and Central Europe) using two types of markers, a mitochondrial gene (12S rDNA region) and 15 nuclear microsatellite loci. In the case of mtDNA, we expected pronounced divergence of $D$. galeata between the two study regions, but low variation within them, as mitochondrial DNA usually has low resolution to detect subtle within-species population differentiation (e.g. [22]). When applying microsatellite markers, we expected to observe significant variation among populations of $D$. galeata, both within and between remote regions. Genetic diversity in this instance is derived from a high number of fast evolving polymorphic loci and, because of their codominant inheritance, discrimination among populations at high resolution is possible [23].

\section{Methods}

\section{Daphnia specimen collection}

Thirteen Chinese and fourteen European Daphnia galeata localities were analysed in this study (Fig. 1). All Chinese lakes are located in the eastern plain (lakes 


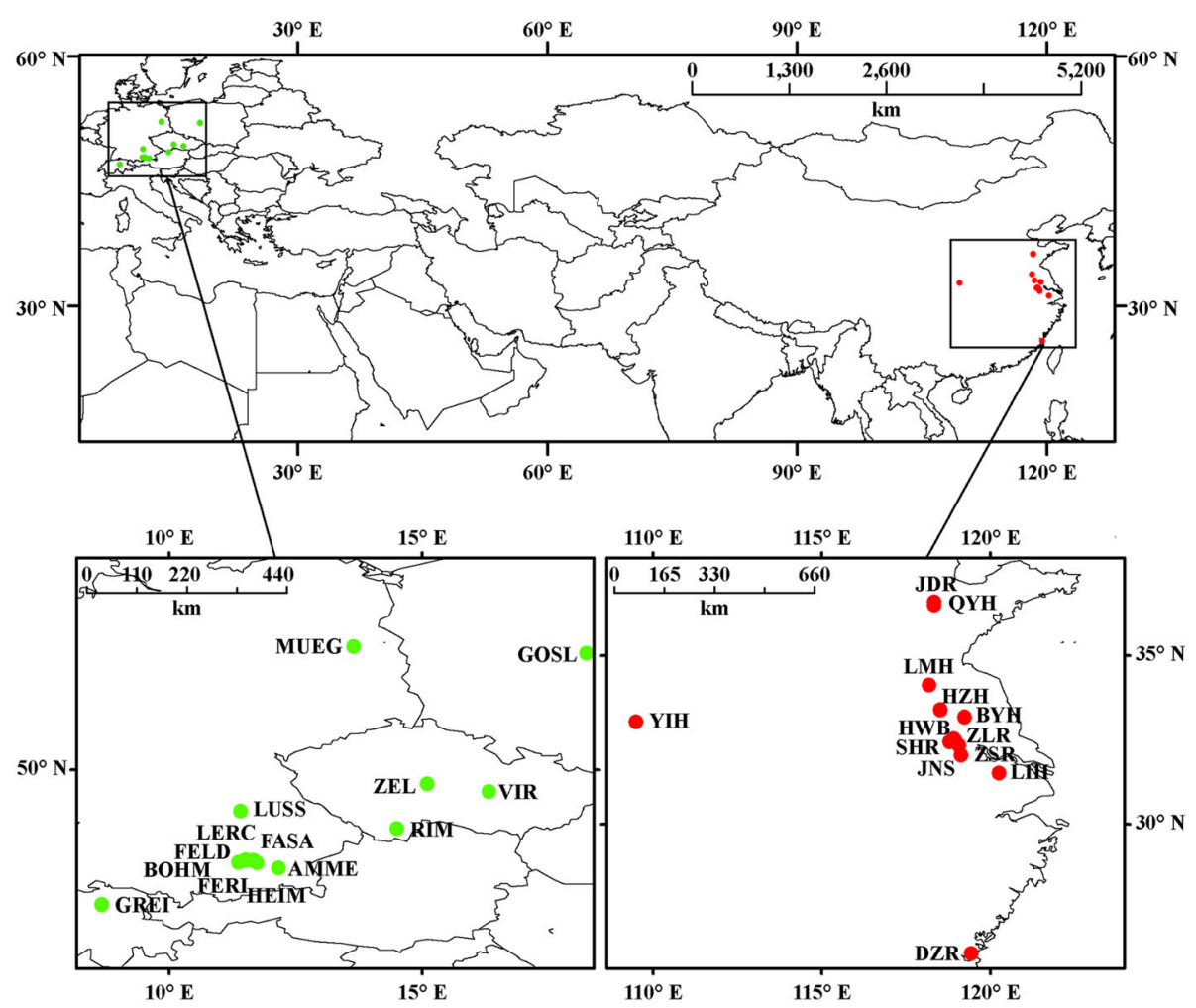

Fig. 1 Location of D. galeata samples from Eastern China (red dots) and Central Europe (green dots)

elsewhere in China are mostly inhabited by another species from the $D$. longispina complex, $D$. dentifera [15]). Among European localities, nine are located in Germany, one in Poland, one in Switzerland and three in Czechia (Table 1). The largest distance among lakes within each region was $1228 \mathrm{~km}$ in China, and $884 \mathrm{~km}$ in Europe; European and Chinese groups of lakes were over $7000 \mathrm{~km}$ apart. Zooplankton samples were collected with a $125-\mu \mathrm{m}$ plankton net hauled through the whole water column at two to three different sites per lake (for sampling years and seasons see Table 1). Samples from different locations within lakes were pooled and preserved in 95\% ethanol.

\section{Nuclear DNA (microsatellites) \\ Genotyping}

Thirteen Chinese and twelve European D. galeata populations were processed for analyses of microsatellites. The individual DNA extractions followed the protocol reported in [24]. Fifteen microsatellite loci [25] were amplified in two multiplex polymerase chain reactions [24]. The PCR products were then analysed on an ABI PRISM 3730 capillary sequencer, using a LIZ 500 labelled size standard. For each run, a reference $D$. galeata genotype (G100 from Europe) was used as a positive control to adjust for small differences in fragment length of identical alleles among runs. Genotypes were scored using GeneMapper version 3.7 (Applied Biosystems), and the alleles at each locus were defined by their fragment length (in base pairs). About 40 adult D. galeata females were genotyped from each Chinese population (except for SHR: 22 individuals, Table 1; 521 individuals in total). In Europe, D. galeata often coexists with other species from the D. longispina complex (e.g. [14, 24]). Recurrent hybridization has been reported [26-28] which requires careful multi-locus species identification $[24,29,30]$. Thus, only true $D$. galeata specimens (based on Bayesian analyses of microsatellite data and comparison of obtained results with reference species $[19,24])$ were included in the analyses of European populations (about 40 individuals per population, except for AMME: 12 individuals, Table 1; 483 individuals in total). In addition to 14 newly sampled and genotyped populations, microsatellite analyses included data that have already been published from eight Chinese and three European lakes $[19,24]$ (see Table 1).

\section{Verification of taxonomic assignment of Chinese and European D. galeata}

We applied Factorial Correspondence Analysis (FCA) on all $25 \mathrm{D}$. galeata populations, with similar settings to those previously used in [19]. Forty-nine well-defined genotypes, representing three species of the $D$. longispina complex (D. galeata, D. longispina and D. cucullata) 
Table 1 Genetic diversity of Daphnia galeata populations from Eastern China and Central Europe, based on 15 microsatellite loci and a mitochondrial gene (for 125 rRNA)

\begin{tabular}{|c|c|c|c|c|c|c|c|c|c|c|c|c|c|}
\hline & \multirow{2}{*}{$\begin{array}{l}\text { Locality (abbreviation), } \\
\text { habitat type, country }\end{array}$} & \multirow{2}{*}{$\begin{array}{l}\text { Sampling } \\
\text { period }\end{array}$} & \multirow{2}{*}{$\begin{array}{l}\text { Latitude, } \\
\text { longitude }\end{array}$} & \multicolumn{5}{|c|}{ Microsatellites } & \multicolumn{5}{|l|}{125} \\
\hline & & & & $\mathrm{N}_{\text {mic }}$ & $\mathrm{N}_{\mathrm{MLG}}$ & MLG & $\mathrm{R}$ & $A_{r}$ & $\mathrm{~N}_{\mathrm{seq}}$ & $N_{\text {hapl }}$ & $h$ & $\pi$ & haplotypes ( $\left.\mathrm{N}_{\text {ident }}\right)$ \\
\hline \multirow[t]{14}{*}{ Europe } & $\begin{array}{l}\text { Ammersee (AMME) } \\
\text { natural lake, } \mathrm{DE}\end{array}$ & $\begin{array}{l}\text { Autumn } \\
2008\end{array}$ & $\begin{array}{l}48^{\circ} 02^{\prime} \\
11^{\circ} 42^{\prime}\end{array}$ & 12 & 12 & 11 & 0.91 & 2.57 & n.a. & & & & \\
\hline & $\begin{array}{l}\text { Böhmerweiher }(\mathrm{BOHM})^{\mathrm{c}} \text {, } \\
\text { small flooded gravel pit, DE }\end{array}$ & $\begin{array}{l}\text { Spring } \\
2008\end{array}$ & $\begin{array}{l}48^{\circ} 10^{\prime} \\
11^{\circ} 22^{\prime}\end{array}$ & n.a. & & & & & 13 & 3 & 0.29 & 0.00067 & $\begin{array}{l}\text { CES (11), BOHMa } \\
\text { (1), BOHMb (1) }\end{array}$ \\
\hline & $\begin{array}{l}\text { Fasanariesee (FASA), small flooded } \\
\text { gravel pit, DE }\end{array}$ & $\begin{array}{l}\text { Spring } \\
2011\end{array}$ & $\begin{array}{l}48^{\circ} 12^{\prime} \\
11^{\circ} 31^{\prime}\end{array}$ & 43 & 41 & 17 & 0.40 & 2.30 & 10 & 1 & 0 & 0 & CES (10) \\
\hline & $\begin{array}{l}\text { Feldmochinger See (FELD), } \\
\text { small flooded gravel pit, DE }\end{array}$ & $\begin{array}{l}\text { Spring } \\
2009\end{array}$ & $\begin{array}{l}48^{\circ} 07^{\prime} \\
11^{\circ} 18^{\prime}\end{array}$ & 46 & 44 & 33 & 0.74 & 2.29 & 10 & 1 & 0 & 0 & CES (10) \\
\hline & $\begin{array}{l}\text { Feringasee }(F E R I)^{a, c} \text {, small flooded } \\
\text { gravel pit, DE }\end{array}$ & $\begin{array}{l}\text { Spring } \\
2009\end{array}$ & $\begin{array}{l}48^{\circ} 07^{\prime}, \\
11^{\circ} 24^{\prime}\end{array}$ & 32 & 31 & 31 & 1 & 2.80 & 19 & 3 & 0.20 & 0.00071 & $\begin{array}{l}\text { ESa (17), FERla } \\
\text { (1), FERIb (1) }\end{array}$ \\
\hline & $\begin{array}{l}\text { Greifensee (GREI), natural } \\
\text { lake, CH }\end{array}$ & $\begin{array}{l}\text { Spring } \\
2002\end{array}$ & $\begin{array}{l}47^{\circ} 20^{\prime} \\
08^{\circ} 40^{\prime}\end{array}$ & 36 & 35 & 21 & 0.59 & 3.49 & 10 & 2 & 0.53 & 0.00232 & CES (6), ESb (4) \\
\hline & $\begin{array}{l}\text { Goslawskie (GOSL), natural } \\
\text { lake, PL }\end{array}$ & $\begin{array}{l}\text { Spring } \\
2014\end{array}$ & $\begin{array}{l}52^{\circ} 18^{\prime} \\
18^{\circ} 15^{\prime}\end{array}$ & 43 & 36 & 31 & 0.86 & 4.25 & 10 & 2 & 0.36 & 0.00232 & ESb (2), GOSLa (8) \\
\hline & $\begin{array}{l}\text { Heimstettener See }(\mathrm{HEIM})^{\mathrm{a}} \text {, } \\
\text { small flooded gravel pit, DE }\end{array}$ & $\begin{array}{l}\text { Spring } \\
2008\end{array}$ & $\begin{array}{l}48^{\circ} 06^{\prime} \\
11^{\circ} 26^{\prime}\end{array}$ & 46 & 43 & 43 & 1 & 3.06 & n.a. & & & & \\
\hline & $\begin{array}{l}\text { Lerchenauer See (LERC), } \\
\text { small flooded gravel pit, DE }\end{array}$ & $\begin{array}{l}\text { Spring } \\
2011\end{array}$ & $\begin{array}{l}48^{\circ} 12^{\prime} \\
11^{\circ} 32^{\prime}\end{array}$ & 45 & 44 & 31 & 0.70 & 3.07 & 10 & 1 & 0 & 0 & CES (10) \\
\hline & $\begin{array}{l}\text { Lußsee (LUSS), small flooded gravel } \\
\text { pit, DE }\end{array}$ & $\begin{array}{l}\text { Spring } \\
2008\end{array}$ & $\begin{array}{l}49^{\circ} 12^{\prime} \\
11^{\circ} 25^{\prime}\end{array}$ & n.a. & & & & & 12 & 2 & 0.17 & 0.00037 & CES (11), LUSSa (1) \\
\hline & $\begin{array}{l}\text { Mueggelsee (MUEG), natural } \\
\text { lake, DE }\end{array}$ & $\begin{array}{l}\text { Spring } \\
2016\end{array}$ & $\begin{array}{l}52^{\circ} 26^{\prime} \\
13^{\circ} 38^{\prime}\end{array}$ & 46 & 46 & 32 & 0.69 & 3.74 & 10 & 3 & 0.51 & 0.00385 & $\begin{array}{l}\text { ESa (7), ESb (2), } \\
\text { MUGGa (1) }\end{array}$ \\
\hline & $\begin{array}{l}\text { Římov }(\mathrm{RIM}) \text {, man-made } \\
\text { reservoir, CZ }\end{array}$ & $\begin{array}{l}\text { Autumn } \\
2009\end{array}$ & $\begin{array}{l}48^{\circ} 50^{\prime} \\
14^{\circ} 30^{\prime}\end{array}$ & 46 & 46 & 31 & 0.67 & 3.40 & n.a. & & & & \\
\hline & $\begin{array}{l}\text { Vír (VIR), man-made reservoir, } \\
\text { CZ }\end{array}$ & $\begin{array}{l}\text { Autumn } \\
2009\end{array}$ & $\begin{array}{l}49^{\circ} 34^{\prime} \\
16^{\circ} 19^{\prime}\end{array}$ & 46 & 16 & 15 & 0.93 & 3.71 & 10 & 3 & 0.38 & 0.00174 & $\begin{array}{l}\text { CES (8), ESa (1), } \\
\text { ESb (1) }\end{array}$ \\
\hline & $\begin{array}{l}\text { Želivka (ZEL), man-made } \\
\text { reservoir, CZ }\end{array}$ & $\begin{array}{l}\text { Summer } \\
2009\end{array}$ & $\begin{array}{l}49^{\circ} 43^{\prime} \\
15^{\circ} 06^{\prime}\end{array}$ & 42 & 35 & 31 & 0.88 & 4.11 & 10 & 3 & 0.51 & 0.00358 & $\begin{array}{l}\text { CES (1), ESa (2), } \\
\operatorname{ESb}(7)\end{array}$ \\
\hline \multirow[t]{11}{*}{ China } & $\begin{array}{l}\text { Baoying } \mathrm{Hu}(\mathrm{BYH})^{\mathrm{b}, \mathrm{d}} \text {, } \\
\text { natural lake }\end{array}$ & $\begin{array}{l}\text { Spring } \\
2012\end{array}$ & $\begin{array}{l}33^{\circ} 06^{\prime} \\
119^{\circ} 08^{\prime}\end{array}$ & 39 & 34 & 34 & 1 & 3.75 & 10 & 2 & 0.20 & 0.00218 & HS1 (9), CES (1) \\
\hline & $\begin{array}{l}\text { Hewangba Reservoir }(H W B)^{b} \text {, } \\
\text { man-made reservoir }\end{array}$ & $\begin{array}{l}\text { Spring } \\
2013\end{array}$ & $\begin{array}{l}32^{\circ} 32^{\prime} \\
118^{\circ} 50^{\prime}\end{array}$ & 40 & 35 & 17 & 0.47 & 2.37 & 10 & 3 & 0.51 & 0.00121 & $\begin{array}{l}\text { HS1 (7), HWBa } \\
(2), \mathrm{HWBb}(1)\end{array}$ \\
\hline & $\begin{array}{l}\text { Hung-tse Lake }(\mathrm{HZ} H)^{\mathrm{b}, \mathrm{d}} \text {, } \\
\text { natural lake }\end{array}$ & $\begin{array}{l}\text { Spring } \\
2012\end{array}$ & $\begin{array}{l}33^{\circ} 13^{\prime} \\
118^{\circ} 18^{\prime}\end{array}$ & 44 & 40 & 29 & 0.72 & 3.08 & 10 & 1 & 0 & 0 & HS1 (10) \\
\hline & $\begin{array}{l}\text { Jinniushan Reservoir (JNS) } \\
\text { man-made reservoir }\end{array}$ & $\begin{array}{l}\text { Spring } \\
2013\end{array}$ & $\begin{array}{l}32^{\circ} 28^{\prime} \\
118^{\circ} 57^{\prime}\end{array}$ & 42 & 37 & 18 & 0.47 & 2.24 & 10 & 2 & 0.53 & 0.00116 & HS1 (4), HS4 (6) \\
\hline & $\begin{array}{l}\text { Luoma Hu }(\mathrm{LMH})^{\mathrm{b}, \mathrm{d}} \text {, natural } \\
\text { lake }\end{array}$ & $\begin{array}{l}\text { Autumn } \\
2012\end{array}$ & $\begin{array}{l}34^{\circ} 07^{\prime} \\
118^{\circ} 11^{\prime}\end{array}$ & 43 & 33 & 33 & 1 & 3.17 & 10 & 2 & 0.53 & 0.00116 & HS1 (6), HS4 (4) \\
\hline & $\begin{array}{l}\text { Shanhu Reservoir }(\mathrm{SHR})^{\mathrm{b}} \\
\text { man-made reservoir }\end{array}$ & $\begin{array}{l}\text { Spring } \\
2013\end{array}$ & $\begin{array}{l}32^{\circ} 26^{\prime} \\
118^{\circ} 47^{\prime}\end{array}$ & 22 & 17 & 17 & 1 & 2.50 & 10 & 1 & 0 & 0 & HS1 (10) \\
\hline & $\begin{array}{l}\text { Zaolin Reservoir }(Z L R)^{\mathrm{b}}, \\
\text { man-made reservoir }\end{array}$ & $\begin{array}{l}\text { Spring } \\
2013\end{array}$ & $\begin{array}{l}32^{\circ} 20^{\prime} \\
119^{\circ} 04^{\prime}\end{array}$ & 42 & 34 & 31 & 0.91 & 2.50 & 10 & 1 & 0 & 0 & HS1 (10) \\
\hline & $\begin{array}{l}\text { Zhongshan Reservoir } \\
(\mathrm{ZSR})^{\mathrm{b}, \mathrm{d}} \text {, man-made reservoir }\end{array}$ & $\begin{array}{l}\text { Autumn } \\
2012\end{array}$ & $\begin{array}{l}31^{\circ} 37^{\prime} \\
119^{\circ} 04^{\prime}\end{array}$ & 41 & 34 & 22 & 0.64 & 2.30 & 10 & 1 & 0 & 0 & HS1 (10) \\
\hline & Li Hu (LIH), natural lake & $\begin{array}{l}\text { Spring } \\
2012\end{array}$ & $\begin{array}{l}31^{\circ} 19^{\prime} \\
120^{\circ} 09^{\prime}\end{array}$ & 40 & 34 & 34 & 1 & 3.73 & 10 & 5 & 0.84 & 0.00741 & $\begin{array}{l}\text { HS1 (3), CES (3), LIHa } \\
\text { (1), LIHb (1), LIHC (2) }\end{array}$ \\
\hline & $\begin{array}{l}\text { Qinyun } \mathrm{Hu}(\mathrm{QYH})^{\mathrm{d}} \text {, } \\
\text { man-made reservoir }\end{array}$ & $\begin{array}{l}\text { Spring } \\
2012\end{array}$ & $\begin{array}{l}35^{\circ} 54^{\prime} \\
117^{\circ} 48^{\prime}\end{array}$ & 37 & 33 & 25 & 0.75 & 2.65 & 10 & 2 & 0.36 & 0.00387 & HS1 (2), CES (8) \\
\hline & $\begin{array}{l}\text { Jingdong Reservoir (JDR) } \\
\text { man-made reservoir }\end{array}$ & $\begin{array}{l}\text { Spring } \\
2012\end{array}$ & $\begin{array}{l}35^{\circ} 57^{\prime} \\
117^{\circ} 48^{\prime}\end{array}$ & 45 & 24 & 11 & 0.43 & 2.20 & 10 & 1 & 0 & 0 & HS1 (10) \\
\hline
\end{tabular}


Table 1 Genetic diversity of Daphnia galeata populations from Eastern China and Central Europe, based on 15 microsatellite loci and a mitochondrial gene (for 125 rRNA) (Continued)

\begin{tabular}{|c|c|c|c|c|c|c|c|c|c|c|c|c|}
\hline \multirow{2}{*}{$\begin{array}{l}\text { Locality (abbreviation), } \\
\text { habitat type, country }\end{array}$} & \multirow{2}{*}{$\begin{array}{l}\text { Sampling } \\
\text { period }\end{array}$} & \multirow{2}{*}{$\begin{array}{l}\text { Latitude, } \\
\text { longitude }\end{array}$} & \multicolumn{5}{|c|}{ Microsatellites } & \multicolumn{5}{|l|}{$12 S$} \\
\hline & & & $\mathrm{N}_{\text {mic }}$ & $\mathrm{N}_{\mathrm{MLG}}$ & MLG & $\mathrm{R}$ & $A_{r}$ & $N_{\text {seq }}$ & $N_{\text {hapl }}$ & $h$ & $\pi$ & haplotypes $\left(\mathrm{N}_{\text {ident }}\right)$ \\
\hline $\begin{array}{l}\text { Ying Hu }(\mathrm{YIH})^{\mathrm{d}} \text {, } \\
\text { man-made reservoir }\end{array}$ & $\begin{array}{l}\text { Autumn } \\
2012\end{array}$ & $\begin{array}{l}32^{\circ} 37^{\prime} \\
108^{\circ} 54^{\prime}\end{array}$ & 44 & 26 & 21 & 0.80 & 3.06 & 10 & 3 & 0.62 & 0.00465 & $\begin{array}{l}\text { HS1 (6), HS4 } \\
(2), \text { CES (2) }\end{array}$ \\
\hline $\begin{array}{l}\text { Dongzhang Reservoir } \\
\text { (DZR), man-made reservoir }\end{array}$ & $\begin{array}{l}\text { Spring } \\
2013\end{array}$ & $\begin{array}{l}25^{\circ} 42^{\prime} \\
119^{\circ} 16^{\prime}\end{array}$ & 42 & 22 & 13 & 0.57 & 1.34 & 10 & 1 & 0 & 0 & HS1 (10) \\
\hline
\end{tabular}

Microsatellite data published in: ${ }^{a}[24],{ }^{b}$ [19]. $12 S$ data published in: ${ }^{c}$ [42] ${ }^{d}$ [15]. $N_{\text {mic }}$ number of genotyped individuals, $N_{M L G}$ number of genotyped individuals with a complete multilocus genotype (MLG), MLG number of detected multilocus genotypes, $R$ relative clonal richness, $A_{r}$ allele richness, $n . a$. data not available, $N_{\text {sea }}$ number of sequenced individuals, $N_{\text {hapl }}$ number of haplotypes per lake, $h$ haplotype diversity per lake, $\pi$ nucleotide diversity per lake, $N$ ident a number in brackets indicates number of individuals possessing the identical sequence. Haplotype ID: CES: haplotype shared by China and Europe; ES: haplotypes shared among European populations; HS: haplotypes shared among Chinese populations (IDs are consistent with [15]). Countries are indicated by two-letter ISO codes in the second column

and their interspecific hybrids, were included as reference taxa in FCA (the same reference genotypes were used in [24]). Then, NewHybrids [31] was applied to double-check if all FCA-identified individuals were pure $D$. galeata. Since NewHybrids allows the discrimination of only two species and their interspecific hybrids, the relevant species pair combinations (galeata and longispina; galeata and cucullata) were analysed separately. New Hybrids then assigned the newly analysed individuals together with reference individuals into six possible classes (i.e. two parental species and four hybrid classes: F1, F2 hybrids and both backcrosses). The analysis was run for $10^{6}$ iterations after a burn-in of length $10^{6}$, and the probability threshold for taxon identification was set to $90 \%$. Only individuals with pure D. galeata assignments were used further.

\section{Population structure and diversity}

To explore the genetic relationship of $D$. galeata populations between and within regions, a similar FCA was run as described above, but without the reference genotypes. In order to identify genetically homogenous groups across all 25 D. galeata populations, a Bayesian algorithm was applied in STRUCTURE V2.3.4 [32], assuming the existence of $K$ groups. For each tested value of $K$ (i.e. 1 to 25), ten independent runs were performed and, for each run, $10^{5}$ iterations were carried out after a burn-in period of $10^{5}$ iterations. The most likely $K$ was determined by the distribution of $\Delta K$, following the methods of Evanno et al. [33]. Then, for each pre-defined population (i.e. lake), the proportion of individuals classified as belonging to each genetic group was calculated. Two similar runs in STRUCTURE were performed as described above to check for genetically homogenous groups within regions across 13 Chinese (K: 1 to 13 ) and 12 European (K:1 to 12$) D$. galeata populations, respectively. Next, the genetic similarity among populations from different regions was estimated by constructing an Unweighted Pair-Group Method with Arithmetic Mean (UPGMA) dendrogram based on Nei's genetic distances [34], as calculated in MEGA 5 [35]. A hierarchical analysis of molecular variance (AMOVA) was performed in Arlequin 3.11 [36] to partition the genetic variance among $D$. galeata populations into the following components: 1) between regions (i.e. Eastern China and Central Europe), 2) among populations within regions, and 3) among individuals within populations. To estimate genetic differentiation among $D$. galeata populations for each region, the fixation index $F_{S T}$ was calculated in Arlequin 3.11 with $10^{4}$ permutations. Finally, the correlation between pairwise geographical distance and pairwise $F_{S T}$ was computed using a Mantel test $\left(10^{4}\right.$ permutations, in Isolation by Distance Web Service, version 3.15 [37]). The level of genetic diversity in each $D$. galeata population was evaluated by calculating the allelic richness $\left(A_{r}\right)$, in FSTAT v.2.9.3.2 [38]. $D$. galeata from VIR and ZEL (for abbreviations of lakes see Table 1) could not be amplified at locus SwiD15, and this locus was removed from the analysis of allelic richness. Relative clonal richness $(R)$ was calculated for each population as $\mathrm{R}=(\mathrm{G}-1) /(\mathrm{N}-1)$, where $\mathrm{G}$ is the number of genotypes and $\mathrm{N}$ indicates sample size [39]. In the analysis of clonal richness, only individuals characterized at all microsatellite loci were considered (individuals with missing data at locus SwiD15 from VIR and ZEL were also included); i.e. 832 of 1004 genotyped D. galeata individuals, see Table 1. Comparisons of genetic diversity indices between regions (i.e. Chinese vs. European populations) were made using Student's $t$ test. Data were tested for confirmation of a normal distribution by a Kolmogorov-Smirnov test, and deviating variables were transformed using the Rankit function [40].

\section{Mitochondrial DNA (12S gene) Amplification and sequencing}

Thirteen Chinese and eleven European populations were processed for analyses of mtDNA (130 Chinese and 124 European specimens in total, Table 1). DNA was extracted by the proteinase $\mathrm{K}$ method [41]. A 544 bp long segment of the small ribosomal subunit (12S rRNA) was sequenced [15]. The $12 \mathrm{~S}$ sequence data from eight out 
of the thirteen studied Chinese lakes have been published elsewhere [15] as part of a geographical survey of Daphnia communities in China (see Table 1). Additional individuals were genotyped for each of these eight lakes, resulting in exactly ten analysed individuals per Chinese population. In the case of European lakes, 10 to 19 individuals were sequenced per population. Data from two out of the eleven studied European lakes have been published ([42]; see Table 1). Although most individuals in these two populations (BOHM and FERI) belonged to F1 D. galeata $\times D$. longispina hybrids (as identified by 15 microsatellite loci; see [42]), they are included in the present study because their mtDNA sequences represented D. galeata maternal lineages. All newly obtained $12 \mathrm{~S}$ rRNA sequences were submitted to GenBank under accession numbers MH052570-MH052577.

\section{Population diversity and phylogenetic analyses}

Haplotype diversity $(h)$ and nucleotide diversity $(\pi)$ for the $12 \mathrm{~S}$ sequences were calculated in DnaSP Version 5 [43]. Then, genetic diversity indices were compared between Chinese and European populations with Student's $t$ test (data were transformed if necessary, see above). The unique haplotypes were identified in Arlequin, and then aligned together with $12 S$ reference sequences of the $D$. longispina complex, including D. galeata from Asia (Japan) and Europe (see Additional file 1: Table S1), using Clustal W [35]. A phylogenetic tree was constructed by applying the Bayesian method in MrBayes 3.2, considering the estimated best-fit substitution models [44]. Daphnia hrbaceki, a member of the $D$. curvirostris complex genetically close to the D. longispina complex [45], was used as an outgroup. To estimate $12 \mathrm{~S}$ mtDNA gene genealogies, a network analysis of D. galeata haplotypes was performed using Haploviewer [46], based on Bayesian algorithms. Finally, an AMOVA test comparable to that applied to microsatellite data (see above) was run on $12 \mathrm{~S} \mathrm{mtDNA}$ sequence data.

\section{Results}

Nuclear DNA (microsatellites)

Based on polymorphism at 15 microsatellite loci, all 521 Daphnia individuals from Eastern China and 493 individuals from Central Europe samples clustered together with reference $D$. galeata genotypes in the FCA plot (Fig. 2a). Based on NewHybrids, 1004 out of 1014 individuals were assigned to pure $D$. galeata (with $90 \%$ posterior probability). FCA of these D. galeata individuals (without reference genotypes) revealed two main clusters clearly separating Chinese and European populations (Fig. 2b). There was no further separation within the Chinese cluster. However, some D. galeata individuals from European GOSL, VIR and ZEL populations were distinct from individuals from other European populations. Assignment test in STRUCTURE run on the entire $D$. galeata dataset showed that the most appropriate estimate of groups was $K=2$, separating Chinese and European populations (Fig. 3a). In separate STRUCTURE analyses for Chinese and European populations, the most appropriate estimate of groups was $K=2$ and $K=8$, respectively (Fig. 3b and c). A UPGMA tree based on genetic distances confirmed that the Chinese samples were divergent from the European ones (Additional file 2: Figure S1). The observed UPGMA clustering within regions was to a large extent consistent with the assignment by STRUCTURE, especially for Chinese populations. Specifically, both methods revealed two clusters of Chinese populations; however, LMH and LIH populations were inconsistently assigned between these two clusters (compare Fig. 3c and Additional file 2: Figure S1).

The AMOVA showed that most of the variation in the microsatellite dataset was explained by a within-population component (48\%) while another significant component was between regions (33\%), followed by within-region variation (19\%; Table 2). Pairwise $F_{S T}$ values ranged from 0.06 to 0.48 among Chinese populations and 0.08 to 0.45 among European populations (averaged over all loci). There was evidence of genetic isolation by distance for Chinese $D$. galeata populations (this remained significant even when two geographically distinct populations, YIH and DZR, were removed; data not shown), but not for European ones (Fig. 4a and b). Neither relative clonal richness nor allelic richness (Table 1 ) differed between the sets of Chinese and European populations $(t=2.06, p=0.99$ and $t=0.37, P=0.53$, respectively). No MLGs were shared among populations on continental or on local scales.

\section{Mitochondrial DNA (12S gene)}

Two hundred fifty-four individuals analysed at the $12 \mathrm{~S}$ rRNA locus (430 bp in the aligned dataset) were assigned to D. galeata (Fig. 5); among these, 17 unique haplotypes were detected (Table 1). The level of haplotype diversity or nucleotide polymorphism within analysed $D$. galeata lineages did not differ between Chinese and European populations $(t=0.07, P=0.26$ and $t=0.31$, $P=0.14$, respectively; Table 1$)$. Generally, there was a separation between Chinese and European haplotypes, which was confirmed by both Bayesian inference of phylogeny and network analysis (Fig. 5a and b); however, one widespread haplotype (CES) was shared among China, Japan and Europe. Two additional haplotypes (HS1, HS4) were shared between China and Japan (Fig. 5a). Shared haplotypes were also observed within the studied regions: three haplotypes (CES, HS1 and HS4) were shared among populations from China, and three (CES, ESa and ESb) among populations from Europe (Fig. 5b, Table 1). An AMOVA test revealed that about six times more genetic variation was attributable to between-region than 

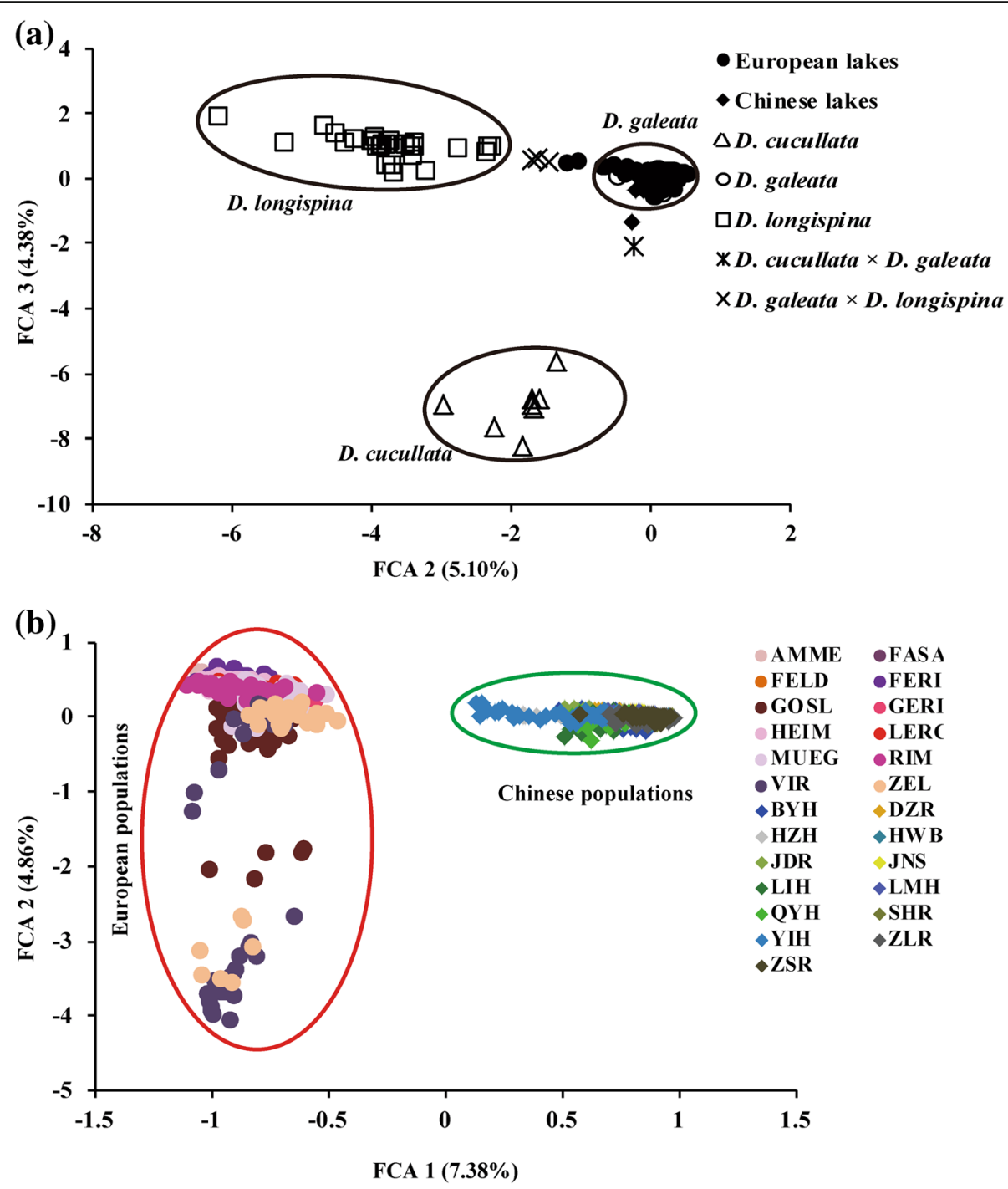

Fig. 2 Results of the Factorial Correspondence Analysis (FCA) based on allelic variation at up to 15 microsatellite loci. a Species assignment of Daphnia individuals from Eastern China and Central Europe. Reference genotypes representing three species of the D. Iongispina complex and their interspecific hybrids (indicated by crosses) are included (for a list of all reference genotypes, see [20]). b Genetic similarities among pure D. galeata individuals sampled from Eastern China and Central Europe. For lake abbreviations see Table 1. Note that analyses in (a) and (b) are independent, and thus the axes are not comparable

within-region (i.e. among-population), or within-population (i.e. among-individuals) levels (Table 2).

\section{Discussion}

In the present study, we compared the patterns of genetic variation in geographically distant populations of a widespread Daphnia species, D. galeata. Specifically, multiple populations of $D$. galeata, sampled from two remote geographical regions (Eastern China and Central Europe), were screened using mitochondrial (12S) and nuclear markers (microsatellites). One of seventeen mitochondrial haplotypes described here was shared between European and Chinese populations. This haplotype (CES) was also widespread within both regions, having been detected in eight out of eleven studied European populations and four out of thirteen Chinese populations. The network analysis (Fig. 5b) demonstrates that this haplotype is closely related to other European haplotypes, and thus likely has a Western Palaearctic origin. Another abundant haplotype, HS1, was detected in all thirteen Chinese habitats, but not in European ones; this might be a founding mtDNA lineage for Chinese haplotypes. The third abundant haplotype, ESa, was shared between four European populations. Notably, the CES and ESa haplotypes were also detected in a 


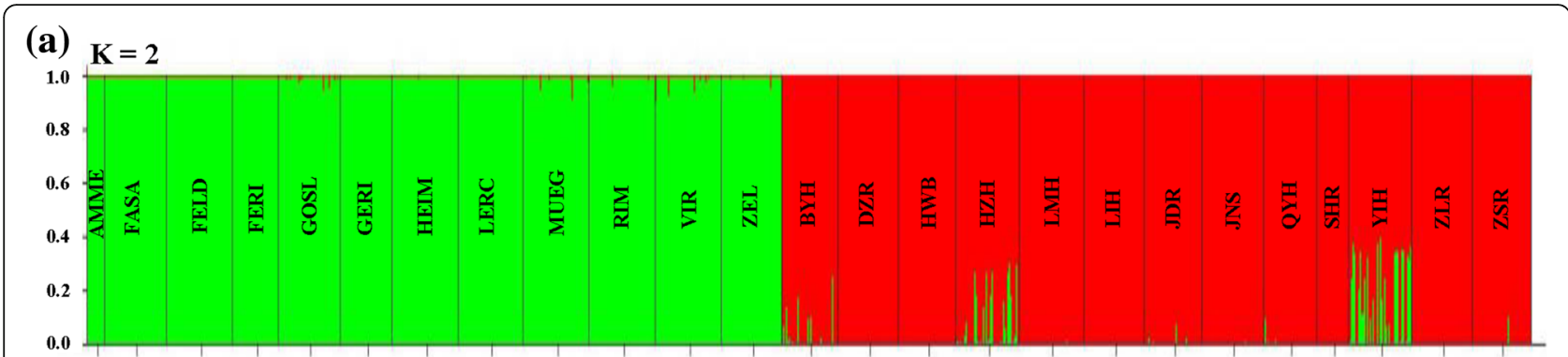

(b)

(c) $K=2$

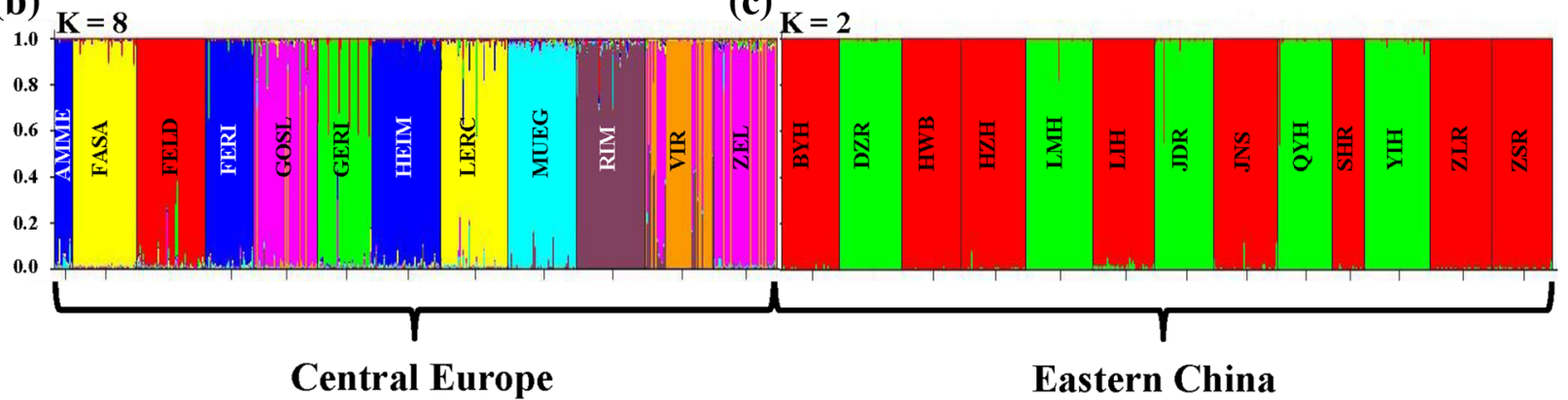

Fig. 3 Results from a Bayesian assignment analysis (STRUCTURE) of microsatellite data for: a all 25 D. galeata populations, b 12 European populations, and $\mathbf{c} 13$ Chinese populations. The best $K$ is equal to $\mathbf{a} 2, \mathbf{b} 8$ and $\mathbf{c} 2$, according to the method reported in [33]. The assignment of each individual to the respective groups is given. For lake abbreviations see Table 1

previous study of European populations of the $D$. longispina complex [47]. There, the CES haplotype was present in D. galeata populations from the Netherlands and Czechia, and the ESa haplotype in populations from the Netherlands.

Based on microsatellite markers, a substantial separation was observed not only between Chinese and European populations, but also within Europe, between three $D$. galeata populations (two Czech: VIR and ZEL, and one Polish: GOSL) and nine remaining populations. The separation of these three populations was well supported by FCA, clustering method based on genetic distances (in Bayesian assignment, some individuals from VIR and most from GOSL and ZEL clustered together) and UPGMA analysis. The clear genetic separation between Chinese and European populations could be explained by the large geographical isolation between these two parts of the Palaearctic. However, the geographical position of localities of D. galeata populations within Europe was not associated with their genetic similarity, suggesting gene flow occurs within regions. A genetic separation of VIR, ZEL and GOSL from other D. galeata populations in Europe might have resulted from introgression of $D$. cucullata to $D$. galeata. In all three localities, we detected $D$. cucullata (although its hybrids with $D$. galeata apparently were not very common in ZEL and VIR [28]), whereas communities of other analysed European lakes often consist of $D$. galeata hybridizing with $D$. longispina [24, 48, 49]. Furthermore, we observed a discordant pattern between mitochondrial and nuclear markers, as some individuals

Table 2 Hierarchical analysis of molecular variance (AMOVA) for D. galeata populations, based on microsatellites and mtDNA, respectively. Between-region (i.e. Eastern China and Central Europe) variation is estimated in relation to within-region and withinpopulation components

\begin{tabular}{lllll}
\hline Marker type & Source of variation & DF & Explained variation (\%) & $P$ \\
\hline Microsatellites & Between regions & 1 & 32.80 & 18.91 \\
& Among populations (within region) & 23 & 48.001 & $<0.001$ \\
& Among individuals (within population) & 1983 & 0.001 \\
mtDNA & Between regions & 1 & 71.67 & $<.005$ \\
& Among populations (within region) & 22 & 12.62 & $<.001$ \\
& Among individuals (within population) & 230 & 15.71 & $<.001$ \\
\hline
\end{tabular}



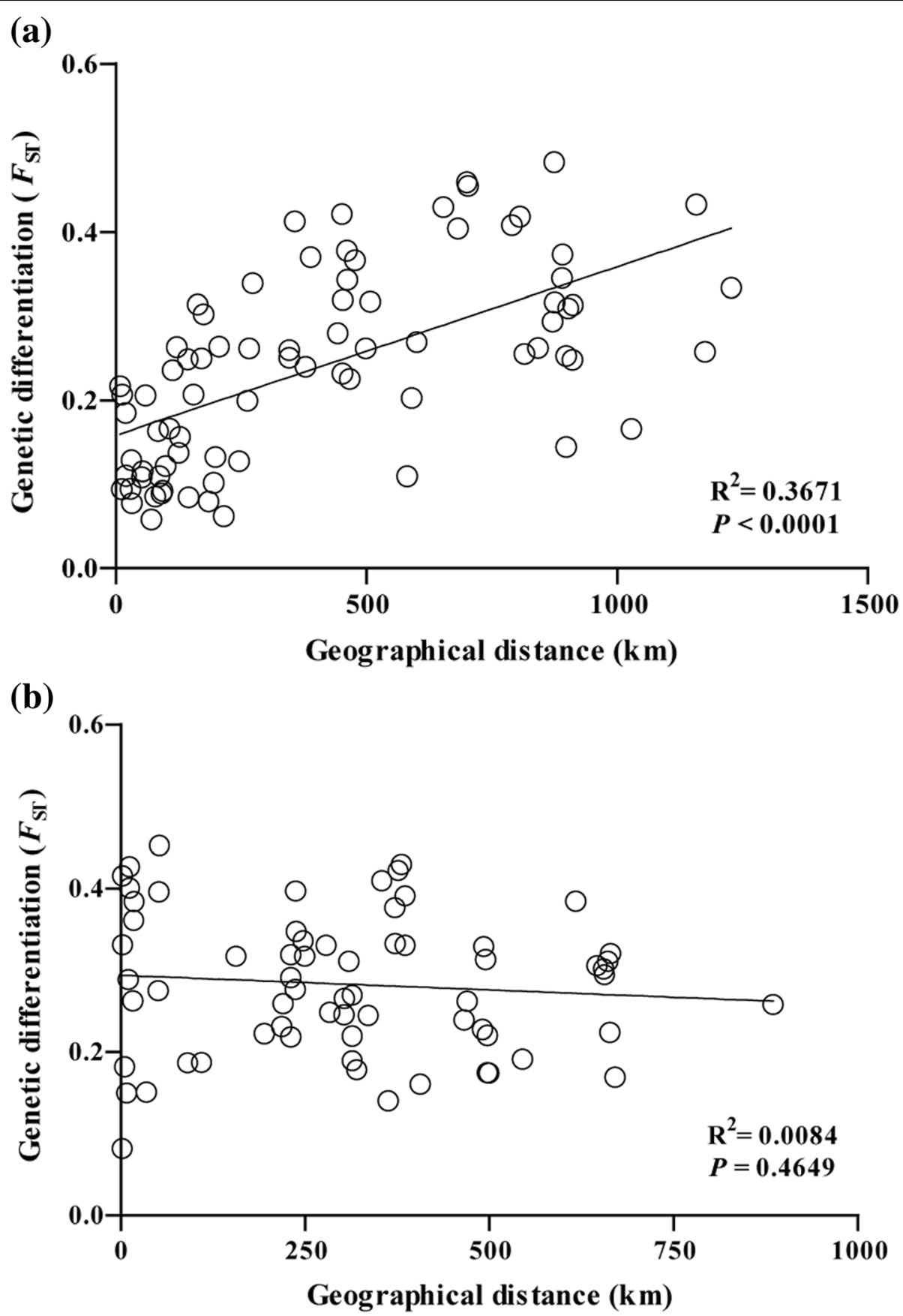

Fig. 4 Scatterplot of pairwise geographical distance (kilometres) versus genetic distance ( $F_{S T}$ based on up to 15 microsatellite loci) among $D$. galeata populations from $\mathbf{a}$ Eastern China and $\mathbf{b}$ Central Europe

from the above localities were classified to $D$. galeata based on microsatellites, but carried D. cucullata mitochondrial haplotypes (data not shown). This suggests that the introgression of the mitochondrial genome occurs after initial hybridization, as observed in other animals (e.g. $[50,51])$.

Interestingly, there was a significant association between genetic distance and geographical distance for $D$. galeata populations from China (but not from Europe). One explanation for the discrepancy could be that studied European $D$. galeata habitats are ecologically more variable than the mostly eutrophic Chinese lakes [52]. In addition to isolation by distance, ecological differences among habitats (i.e., isolation by environment), such as differences in trophic level, could also affect the genetic composition of the $D$. longispina complex assemblages 


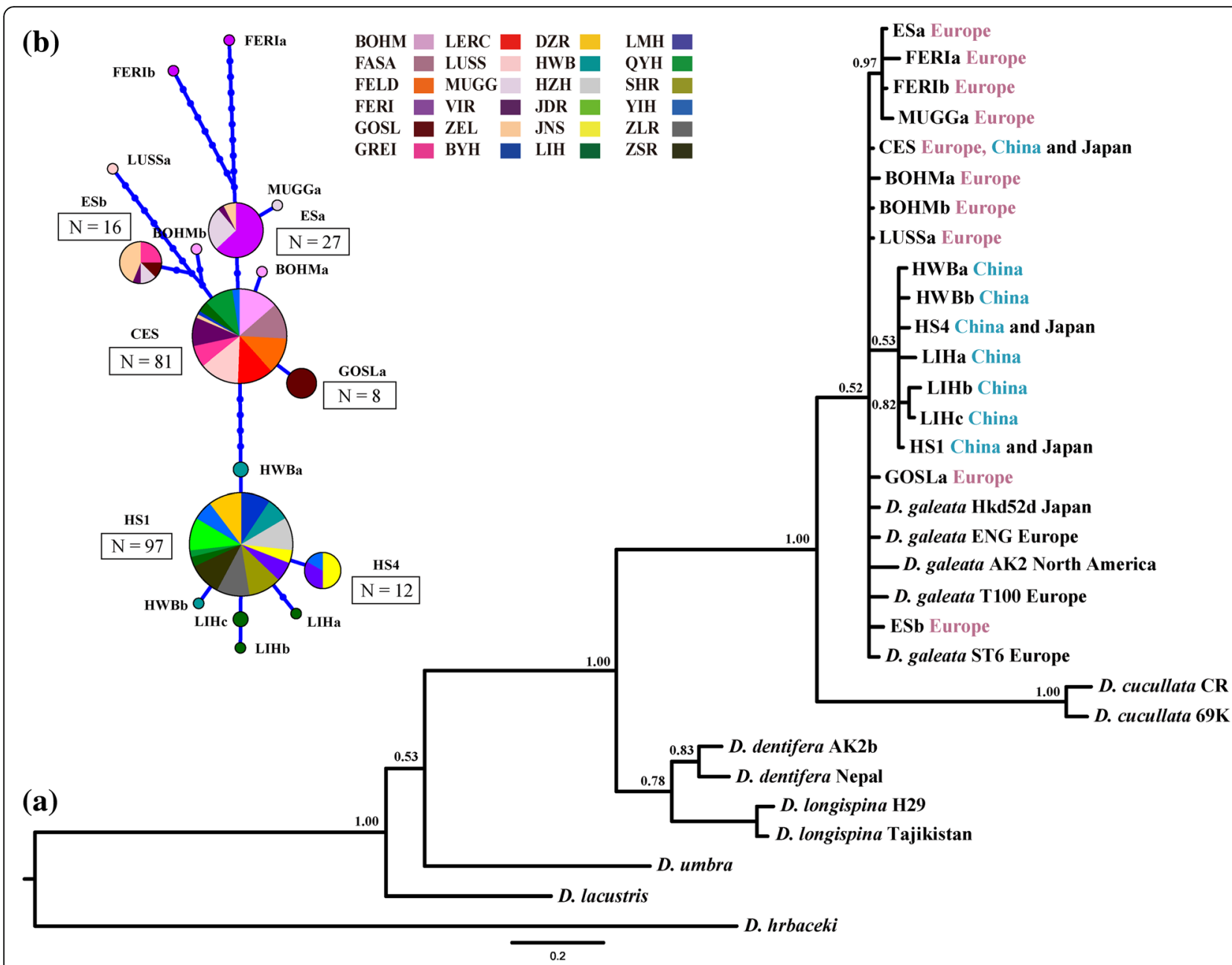

Fig. 5 a Bayesian phylogenetic tree and $\mathbf{b}$ haplotype network of D. galeata, based on the variation of the mitochondrial $12 S$ rRNA gene (430 bp). Codes of Daphnia individuals are provided in Table 1; for origin of reference sequences see Additional file 1: Table S1. Less than 70\% support of nodes is not shown. Daphnia hrbaceki was used as an outgroup. Each circle in $\mathbf{b}$ represents a unique haplotype, and its size reflects the number of individuals carrying that particular haplotype. Segment sizes within circles correlate with the distribution of haplotypes among different populations. Colour codes allow easy discrimination between European populations (purple to red) and Chinese ones (blue, green, grey) in the network. For lake abbreviations see Table 1

[14]. Because of such selective constraints, a pattern of isolation by distance will not always be the rule. Our findings are in line with previous studies on the D. longispina complex where mixed results were reported. Specifically, a significant association between genetic distance (measured by allozyme markers) and geographical distance was detected for other taxa of the D. longispina complex [53] but in a large-scale study of $D$. longispina, no signal for genetic isolation by distance was observed [47].

In general, most of the $D$. galeata populations investigated here, regardless of their origin, showed high relative clonal richness values (as assessed by microsatellites), likely a result of frequent sexual reproduction, which recreates genotypic variation. High clonal richness of $D$. galeata populations was also observed previously (e.g. [47]). However, frequent sexual reproduction in D. galeata populations is not always the case; a substantially lower clonal variation in D. galeata populations was observed in high mountain lakes where populations overwinter under ice, accompanied by a prolonged period of clonal selection [54]. Many populations analysed by us, especially the Chinese ones that are in localities with a mild climate [55], may survive all year round. However, despite possible overwintering by a fraction of the population, these populations also show substantial clonal richness. This might be caused by external conditions promoting genetic polymorphism, such as coevolving parasites $[56,57]$.

\section{Conclusions}

A high number of polymorphic nuclear loci and their codominant inheritance often provide fine resolution in detecting genetic structure [23]. Here, based on a set of 
high resolving microsatellite loci, D. galeata populations from two regions, i.e., Eastern China and Central Europe, were found to be clearly separated from each other, which was confirmed by three types of analyses (FCA, Bayesian assignment and clustering analysis based on genetic distances). This principal finding was supported by mitochondrial DNA data; however, we detected in both regions a common and widespread mtDNA haplotype that was shared across the whole Palaearctic. Our finding calls for further studies to investigate the colonization history of D. galeata, and zooplankton in general, in China and adjacent regions.

\section{Additional files}

Additional file 1: Table S1. Reference sequences of the D. longispina complex used in phylogenetic analyses. (DOCX 15 kb)

Additional file 2: Figure S1. UPGMA clustering of D. galeata populations sampled from Eastern China and Central Europe based on microsatellite polymorphism at 15 loci. For lake abbreviations see Table 1. (TIF $4103 \mathrm{~kb}$ )

\section{Acknowledgements}

We thank Rita Jaenichen, who organized and carried out sampling of European Daphnia and helped with genotyping, Jaromír Seda who designed the sampling campaign in Czech localities, and Piet Spaak and Marcin Dziuba for providing additional samples for genotyping. Finally, we thank Mark Phillipo for the linguistic help and anonymous reviewers for comments on the earlier version of this manuscript.

\section{Funding}

This research was funded by the National Natural Science Foundation of China (31670380) and Natural Science Foundation of Shanghai (16ZR1402900) to MY, and the German Science Foundation grant to JW (WO 1587/6-1).

\section{Authors' contributions}

MY and JW designed the study, MY, XW, XM, AP, JG, WH and JW collected samples, XW, XM and JG carried out the molecular work. MY, XW, XM and JW contributed to data analyses. MY wrote the manuscript, with the help of JW, AP and SG. All authors read and approved the final version.

\section{Ethics approval}

Collection of zooplankton (Daphnia in this study) mostly did not require specific permissions because these samples were usually obtained from unprotected lakes that are open for public activities. Samples from Czech drinking water reservoirs originated from previous sampling campaigns approved by the respective water management authorities. Our study did not involve the use or collection of endangered or protected species.

\section{Consent for publication}

Not applicable.

\section{Competing interests}

The authors declare that they have no competing interests.

\section{Publisher's Note}

Springer Nature remains neutral with regard to jurisdictional claims in published maps and institutional affiliations.

\section{Author details}

${ }^{1}$ MOE Key Laboratory for Biodiversity Science and Ecological Engineering, School of Life Science, Fudan University, Songhu Road, Shanghai 2005, China. ${ }^{2}$ Department Biologie II, Aquatic Evolutionary Ecology, Ludwig-Maximilians-Universität, Großhaderner Str. 2, 82152 Planegg-, Martinsried, Germany. ${ }^{3}$ Faculty of Science, Department of Ecology, Charles
University, Viničná 7, 12844 Prague, Czechia. ${ }^{4}$ Leibniz-Institute of Freshwater Ecology and Inland Fisheries, Department of Ecosystem Research, Mueggelseedamm 301, 12587 Berlin, Germany. ${ }^{5}$ Department of Biology, Chemistry, Pharmacy, Institute of Biology, Freie Universität Berlin, Konigin-Luise-Str. 1-3, 14195 Berlin, Germany.

Received: 14 October 2017 Accepted: 27 August 2018

Published online: 03 September 2018

\section{References}

1. Baas-Becking L. Geobiologie of inleiding tot de milieukunde. The Hague: WP van Stockum and Zoon; 1934.

2. Mayr E. Animal species and evolution. Cambridge: Belknap Press of Harvard University Press; 1963.

3. Gomez A, Carvalho GR, Lunt DH. Phylogeography and regional endemism of a passively dispersing zooplankter: mitochondrial DNA variation in rotifer resting egg banks. Proc R Soc Lond B. 2000;267:2189-97.

4. Penton EH, Hebert PDN, Crease TJ. Mitochondrial DNA variation in North American populations of Daphnia obtusa: continentalism or cryptic endemism? Mol Ecol. 2004:13:97-107.

5. De Meester L. Local genetic differentiation and adaptation in freshwater zooplankton populations: patterns and processes. Ecoscience. 1996;3:385-99.

6. Ventura M, Petrusek A, Miró A, Hamrová E, Buñay D, De Meester L, Mergeay J. Local and regional founder effects in lake zooplankton persist after thousands of years despite high dispersal potential. Mol Ecol. 2014;23:1014-27.

7. Tigano A, Shultz AJ, Edwards SV, Robertson GJ, Friesen VL. Outlier analyses to test for local adaptation to breeding grounds in a migratory arctic seabird. Ecol Evol. 2017;7:2370-81.

8. Lampert W, Sommer U. Limnoökologie. 2nd ed. Suttgart, New York: Georg Thieme Verlag; 1999.

9. Hebert PDN. Genetics of Daphnia. In: Peters RH, De Bernardi R, editors. Daphnia. Mem Ist Ital Idrobiol. 1987;45:439-60.

10. Petrusek A, Hobæk A, Nilssen JP, Skage M, Černý M, Brede N, Schwenk K. A taxonomic reappraisal of the European Daphnia longispina complex (Crustacea, Cladocera, Anomopoda). Zool Scr. 2008:37:507-19.

11. Benzie J. Cladocera: The Genus Daphnia (including Daphniopsis). Ghent, Leiden: Kenobi Productions, Backhuys Publishers; 2005

12. Ishida S, Taylor DJ. Quaternary diversification in a sexual Holarctic zooplankter, Daphnia galeata. Mol Ecol. 2007;16:569-82.

13. Seda J, Kolarova K, Petrusek A, Machacek J. Daphnia galeata in the deep hypolimnion: spatial differentiation of a "typical epilimnetic" species. Hydrobiologia. 2007;594:47-57.

14. Keller B, Wolinska J, Manca M, Spaak P. Spatial, environmental and anthropogenic effects on the taxon composition of hybridizing Daphnia. Philos Trans R Soc B. 2008;363:2943-52.

15. Ma X, Petrusek A, Wolinska J, Giessler S, Zhong Y, Yang Z, Hu W, Yin M. Diversity of the Daphnia longispina species complex in Chinese lakes: a DNA taxonomy approach. J Plankton Res. 2015;37:56-65.

16. Duggan IC, Green JD, Burger DF. First New Zealand records of three nonindigenous zooplankton species: Skistodiaptomus pallidus, Sinodiaptomus valkanovi, and Daphnia dentifera. New Zeal J Mar Fresh Res. 2006;40:561-9.

17. Bilton DT, Freeland JR, Okamura B. Dispersal in freshwater invertebrates. Annu Rev Ecol Syst. 2001;32:159-81.

18. Figuerola J, Green AJ, Michot TC. Invertebrate eggs can fly: evidence of waterfowl-mediated gene flow in aquatic invertebrates. Am Nat. 2005;165: 274-80

19. Wei W, Giessler S, Wolinska J, Ma X, Yang Z, Hu W, Yin M. Genetic structure of Daphnia galeata populations in eastern China. PLoS One. 2015;10: e0120168.

20. Brooks JL. The systematics of North American Daphnia. Mem Connect Acad Arts Sci. 1957;13:1-180.

21. Flößner D, Kraus K. On the taxonomy of the Daphnia hyalina-galeata complex (Crustacea: Cladocera). Hydrobiologia. 1986;137:97-115.

22. Shaw PW, Pierce GJ, Boyle PR. Subtle population structuring within a highly vagile marine invertebrate, the veined squid Loligo forbesi, demonstrated with microsatellite DNA markers. Mol Ecol. 1999:8:407-17.

23. Putman Al, Carbone I. Challenges in analysis and interpretation of microsatellite data for population genetic studies. Ecol Evol. 2014;4:4399-428.

24. Yin M, Wolinska J, Gießler S. Clonal diversity, clonal persistence and rapid taxon replacement in natural populations of species and hybrids of the Daphnia longispina complex. Mol Ecol. 2010;19:4168-78. 
25. Brede N, Thielsch A, Sandrock C, Spaak P, Keller B, Streit B, Schwenk K. Microsatellite markers for European Daphnia. Mol Ecol Notes. 2006;6:536-9.

26. Schwenk K, Spaak P. Ecology and genetics of interspecific hybridization in Daphnia. In: Streit B, Städler T, Lively CM, editors. Evolutionary ecology of freshwater animals. Basel: Birkhäuser Verlag; 1997. p. 199-229.

27. Schwenk K, Posada D, Hebert PDN. Molecular systematics of European Hyalodaphnia: the role of contemporary hybridization in ancient species. Proc R Soc Lond B. 2000;267:1833-42.

28. Petrusek A, Seda J, Macháček J, Ruthová Š, Šmilauer P. Daphnia hybridization along ecological gradients in pelagic environments: the potential for the presence of hybrid zones in plankton. Philos Trans R Soc B. 2008;363:2931-41.

29. Gießler S. Analysis of reticulate relationships within the Daphnia longispina species complex. Allozyme phenotype and morphology. J Evol Biol. 1997;10: 87-105.

30. Dlouhá S, Thielsch A, Kraus R, Seda J, Schwenk K, Petrusek A. Identifying hybridizing taxa within the Daphnia longispina species complex: a comparison of genetic methods and phenotypic approaches. Hydrobiologia. 2010;643:107-22.

31. Anderson EC, Thompson EA. A model-based method for identifying species hybrids using multilocus genetic data. Genetics. 2002;160:1217-29.

32. Pritchard JK, Stephens M, Donnelly P. Inference of population structure using multilocus genotype data. Genetics. 2000;155:945-59.

33. Evanno G, Regnaut S, Goudet J. Detecting the number of clusters of individuals using the software STRUCTURE: a simulation study. Mol Ecol. 2005; 14:2611-20.

34. Nei M. Estimation of average heterozygosity and genetic distance from a small number of individuals. Genetics. 1978;89:583-90.

35. Tamura K, Dudley J, Nei M, Kumar S. MEGA4: molecular evolutionary genetics analysis (MEGA) software version 4.0. Mol Biol Evol. 2007;24:1596-9.

36. Excoffier L, Laval G, Schneider S. Arlequin (version 3.0): an integrated software package for population genetics data analysis. Evol Bioinform. 2005;1:47-50.

37. Jensen JL, Bohonak AJ, Kelley ST. Isolation by distance, web service. BMC Genet. 2005;6:13.

38. Goudet J. FSTAT (version 1.2): a computer program to calculate F-statistics. J Hered. 1995;86:485-6.

39. Dorken ME, Eckert CG. Severely reduced sexual reproduction in northern populations of a clonal plant, Decodon verticillatus (Lythraceae). J Ecol. 2001; 89:339-50.

40. Conover WJ, Iman RL. Rank transformation as a bridge between parametric and non parametric statistics. Am Stat. 1981:35:124-9.

41. Schwenk K, Sand A, Boersma M, Brehm M, Mader E, Offerhaus D, Spaak P. Genetic markers, genealogies and biogeographic patterns in the cladocera. Aquat Ecol. 1998;32:37-51.

42. Griebel J, Gießler S, Yin M, Wolinska J. Parental and hybrid Daphnia from the D. longispina complex: long-term dynamics in genetic structure and significance of overwintering modes. J Evol Biol. 2016;29:810-23.

43. Librado P, Rozas J. DnaSP v5: a software for comprehensive analysis of DNA polymorphism data. Bioinformatics. 2009;25:1451-2.

44. Huelsenbeck JP, Ronquist F. MRBAYES: Bayesian inference of phylogenetic trees. Bioinformatics. 2001;17:754-5.

45. Juračka PJ, Kořinek V, Petrusek A. A new Central European species of the Daphnia curvirostris complex, Daphnia hrbaceki sp. nov. (Cladocera, Anomopoda, Daphniidae). Zootaxa. 2010;2718:1-22.

46. Salzburger W, Ewing GB, von Haeseler A. The performance of phylogenetic algorithms in estimating haplotype genealogies with migration. Mol Ecol. 2011;20:1952-63.

47. Thielsch A, Brede N, Petrusek A, De Meester L, Schwenk K. Contribution of cyclic parthenogenesis and colonization history to population structure in Daphnia. Mol Ecol. 2009;18:1616-28.

48. Keller B, Wolinska J, Tellenbach C, Spaak P. Reproductive isolation keeps hybridizing Daphnia species distinct. Limnol Oceanogr. 2007:52:984-91.

49. Yin M, Gießler S, Griebel J, Wolinska J. Hybridizing Daphnia communities from ten neighbouring lakes: spatio-temporal dynamics, local processes, gene flow and invasiveness. BMC Evol Biol. 2014;14:80.

50. Linnen CR, Farrell BD. Mitonuclear discordance is caused by rampant mitochondrial introgression in Neodiprion (Hymenoptera: Diprionidae) sawflies. Evolution. 2007;61:1417-38.
51. Gompert Z, Forister ML, Fordyce JA, Nice CC. Widespread mito-nuclear discordance with evidence for introgressive hybridization and selective sweeps in Lycaeides. Mol Ecol. 2008;17:5231-44.

52. Le C, Zha Y, Li Y, Sun D, Lu H, Yin B. Eutrophication of lake waters in China: cost, causes, and control. Environ Manag. 2010;45:662-8.

53. Gießler S. Gene flow in the Daphnia longispina hybrid complex (Crustacea, Cladocera) inhabiting large lakes. Heredity. 1997;3:231-41.

54. Hamrová E, Mergeay J, Petrusek A. Strong differences in the clonal variation of two Daphnia species from mountain lakes affected by overwintering strategy. BMC Evol Biol. 2011;11:231.

55. He Y, Theakstone WH, Zhang ZL, Zhang DA, Yao TD, Chen T, Shen YP, Pang HX. Asynchronous Holocene climatic change across China. Quat Res. 2004; 61:52-63.

56. Wolinska J, Spaak P. The cost of being common: evidence from natural Daphnia populations. Evolution. 2009:63:1893-901.

57. Turko P, Tellenbach C, Keller E, Tardent N, Keller B, Spaak P, Wolinska J. Parasites driving host-diversity: incidence of disease correlated with Daphnia clonal turnover. Evolution. 2018;72:619-29.

\section{Ready to submit your research? Choose BMC and benefit from:}

- fast, convenient online submission

- thorough peer review by experienced researchers in your field

- rapid publication on acceptance

- support for research data, including large and complex data types

- gold Open Access which fosters wider collaboration and increased citations

- maximum visibility for your research: over $100 \mathrm{M}$ website views per year

At $\mathrm{BMC}$, research is always in progress.

Learn more biomedcentral.com/submissions 